\title{
Application of the Concept of Healing Environment- in the Design of the Drug Rehabilitation Center in Bali
}

\author{
I Made Hari Wangsa Nugraha ${ }^{1}$, I Gusti Ngurah Anom Rajendra ${ }^{2}$, I Wayan Yuda Manik ${ }^{3}$ \\ Bachelor Degree of Architecture Study Program \\ Faculty of Engineering-Udayana University \\ Jimbaran \\ Hariwangsanugraha.hn@gmail.com \\ Architecture Study Program \\ Faculty of Engineering-Udayana University \\ Jimbaran \\ Architecture Study Program \\ Faculty of Engineering-Udayana University \\ Jimbaran
}

\begin{abstract}
A drug addict (narcotics, psychotropic drugs, and other addictive materials) have a very rapid development in many countries. Country Indonesia included in the country with the number of drugs users are growing rapidly every year, so it needs a facility that is the drug rehabilitation. Drug addict rehabilitation center in Bali is a facility that hosts a drug ad-dict in order to recover the health of body, emotions, mind, and soul. Drug addict rehabilitation facilities have on site medical and non-medical health required for restoring and treating drug addicts and it also helps the Government pro-gram to reduce the drug addict. Drug rehabilitation center is a healing environment designed aiming to accelerate the healing process ang providing service for drug addicts. To achieve these goals, the process of designing a drug addict rehabilitation centre implemented the concept of the healing environment where in this design, the healing process is obatained through the rehabillitan not only medical but also parties obtained from the environment around the rehabili-tan used by rehabillitan as on object design.
\end{abstract}

Index Terms - drug addict, rehabilitation center, healing environment.

\section{INTRODUCTION}

Drug addiction is a disease where the physical and psychological are disturbed so that it causes a dependency on drugs. Indonesia is included in a country that has a fairly large drug abuse, on the other hand the country of Indonesia still does not carry out the regulations that have been made namely drug addicts are not classified as criminal acts but are given care and treatment through rehabilitation of drug addicts who have health function standards and rehabilitation function standards, with the existence of healing activities in the medical and psychological, from the phenomenon found a healing environment that is expected to maximize the activity of the space inside and outside the room. In the application of interior design can follow the drug rehabilitation standards and to maximize the outer space can apply the concept of healing environment that can help a healing process be it psychological, physical, emotional.

\section{RESUlt AND ANALISYS}

\section{A. Healing Environment}

The concept of healing environment is one of the concepts of the formation of the built environment by combining natural, physical, and psychological aspects. The purpose is to apply the concept of healing environment to support the process of adaptation of rehabilitation to the environment and physical rehabilitation. A good adaptation 
process will have an impact on decreasing the level of rehabilitation stress due to the physical environment of drug addiction rehabilitation centers, so that it can help the rehabilitation process of rehabilitation. Dijkstra, healing environment is the physical environment of a health facility that can accelerate the recovery time of rehabilitation health or accelerate the rehabilitation process of rehabilitation by involving the psychological effects of rehabilitation in it.

Murphy [1] explains that there are three approaches used in designing a healing environment, namely natural, sensory and psychological. The natural aspect is a tool that is easily accessible and involves the five senses. As for the elements of the concept of healing environment such as lighting and disposition that have an effect can reduce blood pressure, circulation which can contribute to a positive emotional state, and natural elements that can reduce stress hormone levels and increase energy. The sensory aspects include hearing, sight, touch, smell and taste. The concept of healing environment approach from the aspect of the senses can be measured from the circulation, lighting, nature and natural elements. Meanwhile, in terms of psychological aspects of the healing environment it helps the rehabilitation process to be faster, reducing pain and stress

\section{B. Healing Environment Forming Elements}

The application of healing environment to the design object is very helpful in the process of healing activities that will be carried out. The object of design requires an environment that can help the rehabilitation process so that the treatment period is less and the healing process of rehabilitation is more optimal. The concept of healing environment is very suitable with the needs of the design object in this case the rehabilitation center for drug addicts. Architecture has a role in forming a conducive built environment. To achieve the desired benefits with the healing environment concept approach, several elements that can be observed in the healing environment concept are circulation, lighting, ventilation, and natural elements.

\section{Sirculation}

Circulation is related to the comfort of the wiggle room. Circulation in drug addiction rehabilitation centers uses a dynamic mixed circulation pattern that can accommodate rehabilitators, medical and non-medical personnel, as well as space users to facilitate access between spaces. Things that need to be observed from the technical circulation of drug addiction rehabilitation centers are easy to reach, communicative, informative, slippery free, free of collisions, and comfortable dimensions of circulation (Figure 1). Application of the circulation that is not ideal can cause rehabilitation discomfort in the rehabilitation environment. Rehabilitation discomfort unwittingly can cause stress which can hamper the health recovery process.

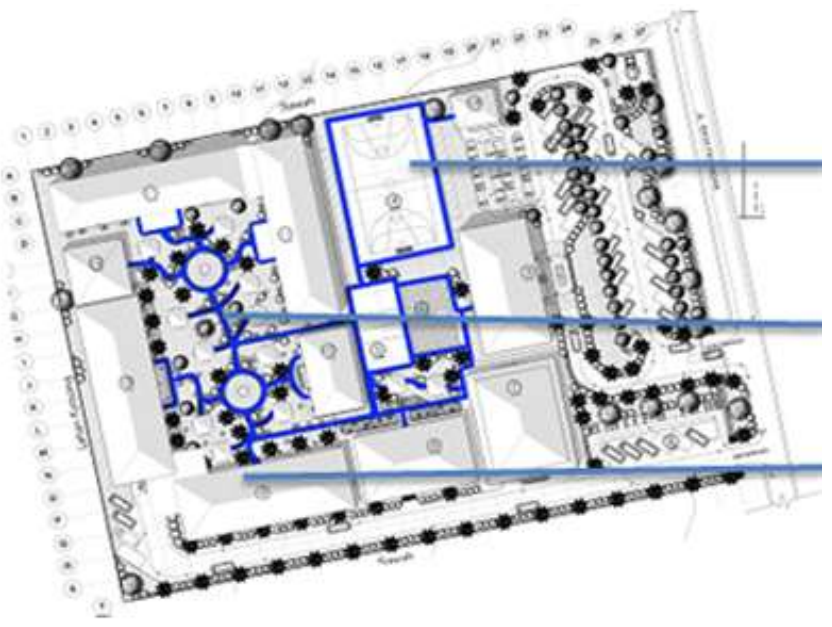

Pada alur sirkulasi rehabilitan, tenaga meds dan nonmedis menggunakan material paving block

Penggunakan pola berbentuk dinamis pada alur sirkulasi agar terciptanya kesan tidak terikat atau tidakformal

Pada be berapa area sirkulasi diberikan sistem penanda yang informatif agar memudahankan para rehabilitan maupun tenaga medis dan nonmedis

Fig. 1. Comfortable Dimensions of Circulation (source: Nugraha)

\section{Lighting}

Darmasetiawan, Christian, and Lestari Puspakesuma describe lighting sources consisting of natural and artificial lighting[2]. Natural lighting is obtained from sunlight, while artificial lighting is obtained from lamps and other lighting sources. Natural lighting that enters the room at a drug addict rehabilitation center is limited so as not to cause an over supply of natural light. Likewise with artificial light, the intentivity of light and color from artificial light need to be considered to be in accordance with the function of space because light can reduce psychological anxiety and can encourage positive emotional rehabilitation (Figure 2). For example, white gives a clean impression in the room, while yellow gives a warm impression. The use of the right color in the right situation will certainly give a sense of comfort to the rehabilitation. Conversely, excessive light intensity and inappropriate light colors can provide psychological discomfort. 


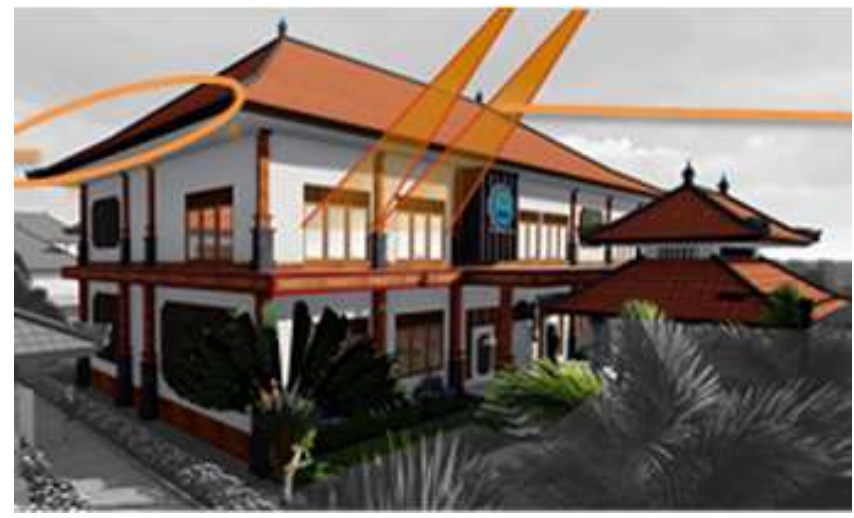

Fig. 2. Natural Lighting (source: Nugraha)

\section{E. Air Sirculation}

Fresh air from outside (outdoor) is very positive impact for rehabilitation. Provision of fresh air in the room through the window and ventilation. Drug addiction rehabilitation center has a rectangular building shape, this is in order to be able to implement cross ventilation so that air circulation in the room becomes smooth. Laying shade trees and ponds in the building is functioned so as to reduce the temperature so that with normal temperatures can affect psychologically and emotionally so as to accelerate the rehabilitation process of rehabilitation.

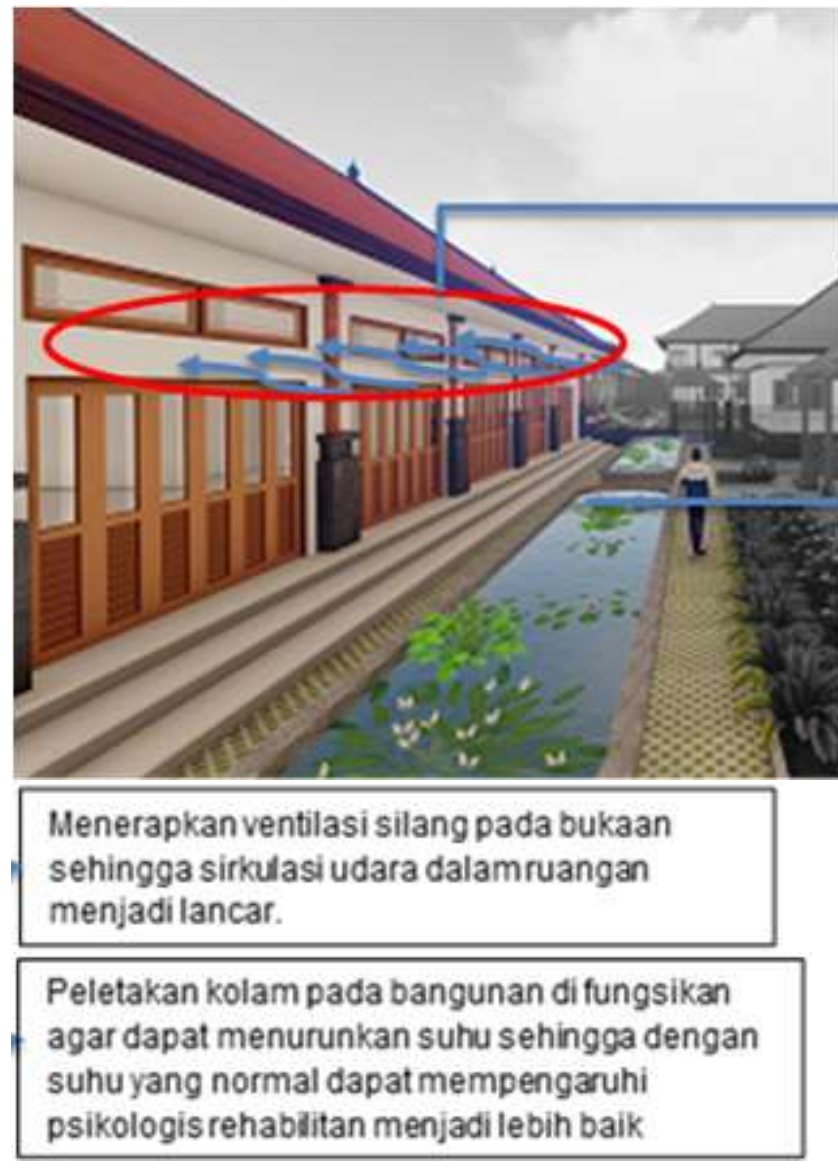

Fig. 3. Air Sirculation (source: Nugraha)

\section{F. Landscape}

Kurniawati [3] Natural elements are processed in order to create an atmosphere that can accelerate the healing process. The natural element plays an important role in the concept of healing environment. In the outer space of the addict rehabilitation center there are various elements of nature such as trees, grass, water, sky, stones, flowers, and birds that contribute to the application of the concept of healing environment to the outer space. The outer space at the drug rehabilitation center offers a different experience, such as there is a privacy area in the gazebo so rehabilitators can enjoy solitude with nature and become a place to gather and socialize by enjoying nature in the area of drug addicts rehabilitation center.
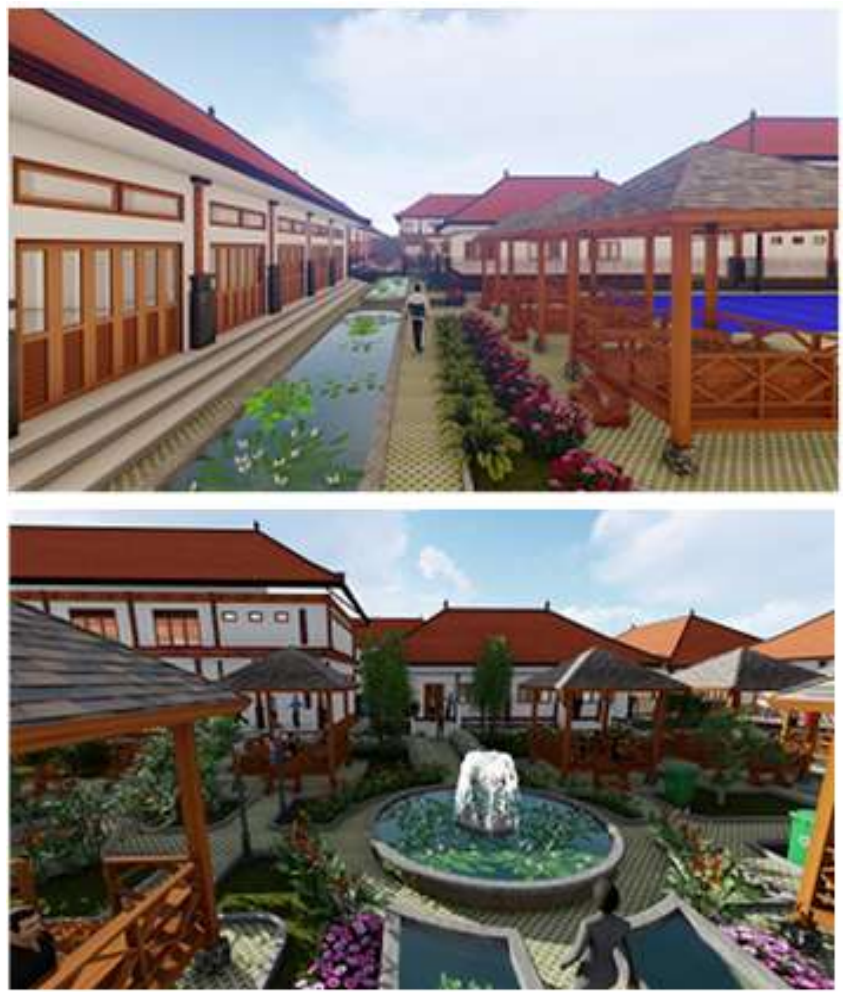

Fig. 4. Hardscape and Softscape (source: Nugraha)

The types of plants selected in the outer space area according to the aroma and shape that can stimulate the five human senses in the outer space area, the types of plants in this area are Allamanda Cathartica, Brunfelsia Pauciflora, Saraca Asoka. In addition, in each of these areas there are two fountain pools, these fountains aim to stimulate the human sense of hearing because the sound of the fountain can make a feeling of calm and comfort.

\section{CONCLUSION}

The application of the concept of healing environment in the design of a rehabilitation center for drug addicts in Bali in order to produce a comfortable building design both psychological and physical rehabilitation. The concept of healing environment supports the rehabilitation process of rehabilitation. The condition of the surrounding natural environment is very important to protect because the concept of healing environment is very closely related to the 
natural environment. Architecture also has a role in creating a comfortable space by using the concept of healing environment, thus healing the existing drug rehabilitation process will be faster so that the recovery process can run optimally.

\section{REFERENCES}

[1] Murphy, Jenna, "The Healing Environment”, 2008.

[2] Darmasetiawan, Christian, Lestari Puspakesuma, "Teknik Pencahayaan dan Tata Letak Lampu Jilid 1 Pengetahuan Dasar", Jakarta: PT. Gramedia Widiasarana Indonesia, 1991.

[3] Kurniawati, Febriani, “'Peran Healing Environment Terhadap Proses Penyembuhan”, Jurusan Teknik Arsitektur Fakultas Teknik, UGM, 2011. 